\title{
Boccaccio, Baptismal Kinship, and Spiritual Incest
}

\section{LOUIS HAAS}

At baptism much more occurs than just the introduction of another member into the Christian community. During the ritual, by virtue of its spiritual nature, the participants are bound together for life in a web of religious and social obligations and honors. This web is commonly known as baptismal kinship. Most Christian cultures have maintained some form of baptismal kinship, but the specific practice has varied with time, place, and sect. The Catholic Church today, for instance, officially recognizes only a religious bond between the godparents and the godchild. Catholics in Latin America, however, also recognize a religious and social bond between the godparents and the parents. In the European past, before the Reformation-era theologians narrowed the scope of the religious bonds, sponsors at baptism became the ritual kin of both the godchild and the parents. Baptismal kinship thus can - and did - operate on two planes: that of godparenthood (referred to as paternitas in medieval Latin texts), comprising the bonds between the sponsors and the child; and that of coparenthood (referred to as compaternitas in medieval Latin texts), comprising the bonds between the sponsors and the parents. As noted above, for the rest of their lives the individuals within the web of baptismal kinship are supposed to maintain certain responsibilities and duties toward one another. Either the Church or society or both prescribe the boundaries and specifics of these responsibilities and duties. Baptismal kin, for instance, should cultivate a heightened degree of friendship with one another. ${ }^{1}$

Anthropologists have long known the significance of baptismal kinship for various cultures in premodern and modern Latin America. There the practice has performed many functions, such as providing for the education of children, easing the tension of social conflict, or establishing economic and psychological support networks among people. ${ }^{2}$ Recently, anthropologists and historians have begun investigating the significance of baptismal kinship for premodern Europe. Their studies indicate that the various types 
of premodern European baptismal kinship performed many of the same functions that premodern and modern Latin American baptismal kinship has performed. ${ }^{3}$

Premodern European baptismal kinship also established many of the same taboos that premodern and modern Latin American baptismal kinship has established. Perhaps the most signal - and universal - taboo associated with baptismal kinship is the marital impediment it erects for those falling within its web. Simply put, sexual violation of the cognatio spiritualis, the spiritual relationship contracted at baptism, represents spiritual incest. This taboo became codified as early as the Justinian Code (530). ${ }^{4}$ By the thirteenth century, canon law firmly held that sponsors were spiritually related to their godchildren and their godchildren's parents. Godchildren were even spiritually related to their sponsor's children. Moreover, some canon lawyers believed that sponsors were spiritually related to the other sponsors at the ceremony. None of these individuals could engage in carnal relations, let alone marry one another. In his Summa Theologica, Thomas Aquinas (1225-74) took note of a popular verse: "I may not marry my own child's godmother nor the mother of my godchild."5 Throughout the Middle Ages, canon lawyers, theologians, bishops, and preachers all repeatedly outlined the boundaries of spiritual incest and the consequences of crossing those boundaries. But how much of this normative advice penetrated to the popular level? ${ }^{6}$

Seven of Boccaccio's stories in The Decameron (1348-52) describe elements of baptismal kinship, and two of these emphasize the spiritual incest taboo. ${ }^{7}$ Since these baptismal kinship elements are new additions to some old motifs, Boccaccio must have drawn them from the pool of Florentine popular belief. ${ }^{8}$ What did Florentines believe about the spiritual incest taboo?

In the Tenth Story for the Seventh Day, two Sienese, Tingoccio and Meuccio, are great friends and make a pact that the first one who dies will come back and tell the other what the afterlife is like. This of course is an old motif and the source of jokes even today. ${ }^{10}$ Boccaccio, however, complicates his story with details of baptismal kinship:

After this promise had been made and as they continued to be close friends it happened that Tingoccio became cofather (compare) to one Ambruogio Anselmini of Camporeggio and his wife, Monna Mita. Tingoccio, in the company of Meuccio, would visit his comother (comare) rather frequently and in spite of their spiritual relationship (il comparatico) he fell in love with her, for she was a beautiful and charming woman; and since Meuccio found her pleasing and because he would 
often hear Tingoccio praise her, he fell in love with her too. And each one avoided speaking about his love to the other, but for different reasons: Tingoccio kept from revealing it to Meuccio because of the wickedness (la cattività) he himself saw in loving his comother, and he would have been ashamed if any one had learned of it; Meuccio did not do so because he noticed that she pleased Tingoccio so much; whereupon he said to himself:

"If I reveal this to him, he will become jealous of me, and since he can speak to her whenever he likes, for he is her cofather, he might make her dislike me, and so I may never get what I want from her."

This passage illustrates well the close familiarity that was part of baptismal kinship. Tingoccio visited his comother frequently, even before he fell in love with her. Meuccio recognized the special closeness Tingoccio enjoyed with Monna Mita by virtue of his status as her cofather; in fact, he is miffed that Tingoccio has such free access to her, noting that "he can speak to her whenever he likes, for he is her cofather."

In this case, however, the familiarity blossomed into something more intimate - and taboo. Despite his feelings of affection for Monna Mita, Tingoccio still considered it wicked that he had fallen in love with her. His conscience thus troubled him over these feelings, but he also feared society's reaction. He noted how he would be ashamed if people knew he loved his comother. Boccaccio's description of Tingoccio's guilty and shameful reaction to falling in love with his comother shows that medieval Florentines knew of and accepted the taboo against sexual relations among baptismal kin. They would have understood why Tingoccio felt guilty and ashamed.

Tingoccio's passion for Monna Mita, however, overwhelmed his sense of taboo and he consummated his desire: "and then it happened that Tingoccio, who was more skillful [than Meuccio] at revealing his feelings to the lady, was so clever in word and deed that he had the pleasure of her." 12 He crossed the boundary of spiritual incest, and then he died. Crossing that boundary may have contributed to his death. "The fact was that Tingoccio found himself in possession of the lady's fertile terrain, and he so spaded and plowed it over that an illness struck him which, after several days, grew worse; and unable to bear it any longer, he passed from this life." 13 Now Tingoccio would discover the consequences of crossing the boundary of spiritual incest.

True to his word, Tingoccio reappeared before Meuccio and told him about the afterlife and how he was suffering terrible punishment for his sins. Meuccio, who had known that Tingoccio had had an affair with 
Monna Mita, asked him what punishment this entailed. "I just remembered, Tingoccio,' he said, 'for sleeping with your comother what punishment did they give you?" "14 Here Meuccio assumed that Tingoccio would suffer in the afterlife for committing spiritual incest, and at first so did Tingoccio:

"Brother, when I arrived here, there was someone who seemed to know
everyone of my sins by heart, and he ordered me to go to a place in
which I lamented my sins in extreme pain and where I found many
companions condemned to the same punishment as I was; and standing
there among them and remembering what I had done with my comother,
I trembled with fear, for I expected an even greater punishment for that
than the one I had already received - although, in fact, I was at that
moment standing in a huge and very hot fire. And as one of those
suffering at my side noticed this, he asked me: " "Why do you tremble standing in the fire? Have you done something worse than the others who are here?'

“ 'Oh, my friend,' I answered, 'I am terrified of the judgement which I expect to be passed on me for a great sin that I have committed.'

"Then that soul asked me what sin it was, and I replied:

" "The sin was this: I slept with my comother, and I made love to her so much that I wore it to the bone.'

"Then laughing at me he said:

“ 'Go on, you idiot, don't worry, for down here they don't count comothers for very much!' And when I heard this, it made me feel much better."

When Meuccio heard that in the other world they did not care whether you did it with your comother, he began to laugh at his stupidity for having spared a number of such women, and abandoning his ignorance, he became wiser in such matters for that time on. ${ }^{15}$

So Meuccio learned a valuable lesson here. According to his friend Tingoccio, he no longer had to accept the spiritual incest taboo, which he had always honored before. Now we too learn a valuable lesson here. What is interesting about this story is something that Robert Darnton has called the joke we as twentieth-century intruders into a past culture do not understand. ${ }^{16}$ For those of us who no longer recognize any significant bond or taboo among baptismal kin this story is confusing, even inexplicable. We do not get the joke. But if we are aware of the sexual taboos arising out of medieval baptismal kinship and if we assume that perceptions of these taboos penetrated to the popular level - or at least the level of the literate 
in Florence - then the story becomes not only understandable but quite humorous, as it must have been to medieval Florentines. The text of The Decameron here only makes sense when we realize and understand its context, that is, the cultural reality (the signposts, if you will) around which Boccaccio structured his story. Yet, the text itself helps identify that context for us. Thus to fully appreciate the cultural reality of The Decameron, we, as alien intruders into a past culture, need to work ourselves back and forth between text and context. So, where would Florentines have learned about the sexual taboos arising out of, as they phrased it, il comparatico?

Medieval Italian Church records in general and Florentine Church records in particular are sketchy and sparse, not only due to the hazards of time and the accidents of survival but also due to the lackadaisical, desultory, and inefficient nature of most medieval Italian churchmen. ${ }^{17}$ Nevertheless, we have enough evidence to indicate that the Florentine Church hierarchy did try to outline the boundaries and rules of baptismal kinship to its flock. Medieval Florentine bishops commanded rectors to read to their parishioners the Church rules regarding morality. Richard Trexler believes that because of this injunction Florentines probably knew canon law better than they did the civil law of the commune. The Synodal Constitutions of Fiesole (1306) and those of Florence (1310 and 1327) all stated that intentions to marry had to be announced publicly so that potential impediments, including presumably those arising from baptismal kinship, could be discovered and announced too. According to the Council of Florence (1517), banns were to be announced for the two consecutive Sundays before marriage. On these occasions the rector read the list of canonical impediments to marriage, including those arising from baptismal kinship. ${ }^{18}$

In 1517 the Council of Florence defined the cognatio spiritualis (cognatione spirituale) as "that spiritual relationship originating in respect of baptism and confirmation where there are cofathers and comothers (meaning also godmothers and godfathers)" ${ }^{19}$ After noting how people became baptismal kin, the Council declared that those who married their baptismal kin committed incest since the spirit was more important than the body. ${ }^{20}$ This impediment to marriage, the Council decided, should be read to parishioners three times a year, on the Sunday after Easter, the first Sunday in August, and the Feast of the Epiphany. ${ }^{21}$ Also in 1517 the Council ordered priests to keep baptismal registers in order to maintain accurate records of who was connected to whom by the cognatio spiritualis. ${ }^{22}$ This injunction noted that confusion over baptismal kinship relations was rampant, and that without written records people over time sometimes forgot who their 
baptismal kin were or they had never known who they were to begin with. Considering that some Florentines had a dozen godparents, this confusion is understandable. ${ }^{23}$ And this posed a serious religious problem in medieval Florence, since some people tended to marry ignorant that they violated the sexual taboo arising out of spiritual kinship - a problem incidentally rather common in Latin America today.

Yet the Constitutions of Fiesole and Florence had advised annual confession where a confessor might communicate to the penitent the sexual taboos arising from baptismal kinship. ${ }^{24} \mathrm{~A}$ fifteenth-century Florentine confessor's manual, Libro della confesione, dealt with what it called "spiritual sin" (pecchato spirituale). These manuals in general posed questions for the confessor with which he could probe the inner and as it were darker recesses of the penitent's psyche. ${ }^{25}$ Here, in dealing with spiritual sin, this manual advised the confessor to inquire whether his parishioners had committed this sin by having sex with a comother or a goddaughter. This inquiry was also directed at women, for the confessor was to ask them as well if they had had sex with a cofather or a godson. Whether or not the penitent had committed this act, he or she would have had at least an annual warning of the horrors and sinfulness of spiritual incest. Sant' Antonino (1389-1459) in his confessor's manual noted that a priest should ask whether the penitent had heard and understood that sex with a coparent or godchild was spiritual incest. $^{26}$

Florentines also learned about the sexual taboos of baptismal kinship from more personal sources than synodal law or judgmental confessors. San Bernardino, a popular preacher at Florence in the early fifteenth century, reminded his listeners that if they had held children at baptism, they could not marry them. ${ }^{27}$ This is not so bizarre a piece of advice as it might seem considering the wide age differential between husbands and wives in medieval Florence. In their study of the 1427 Catasto, David Herlihy and Christiane Klapisch-Zuber discovered that the average age for brides at Florence was 17.96 years, for grooms 29.5 years - an average differential of 11.99 years. They concluded that "when a Tuscan married, whatever his age or place of residence, he preferred to take as a bride a girl under 20 years, even under $18 . " 28$ Thus the spiritual incest taboos arising from the cognatio spiritualis meant that men sponsoring female children narrowed their possible marriage pool more than when they sponsored male children.

The incest taboo could cause another problem. If parents held their own children at baptism, would they become baptismal kin and their marriage incestuous? There was a real possibility that parents might have to act as 
sponsors for their own children considering the conjunction of two premodern realities, one demographic and the other religious: the high infant mortality rate and the perceived necessity of baptism for salvation. ${ }^{29}$ In the case of a dying newborn who had to be baptized quickly, sometimes even at home, parents might not have the luxury of time to arrange the proper godparents. A parent - or both - might have to stand in.

Nevertheless, despite the human need here, to solve this problem the Constitutions of Fiesole and Florence and the Council of Florence all asserted that parents could not stand as godparents to their children. ${ }^{30}$ These injunctions, curiously, were at variance with canon law elsewhere in Europe, where canon lawyers and theologians held that the cognatio spiritualis furnished only an impediment to marriage. In other words, entering into baptismal kinship prevented a future marriage with these people from occurring; it did not furnish grounds to dissolve one that had already taken place. ${ }^{31}$

It would seem, despite the fragmentary nature of our sources, that Florentines had ample chance to hear information indicating that baptismal kin could not marry and that their sexual congress was forbidden as well. Again, one of Boccaccio's stories reflects that fact.

In the Third Story for the Seventh Day, a fine fellow by the name of Rinaldo falls in love with his neighbor's wife, Agnessa:

and hoping, if only he could find a means of talking with her without raising suspicion, to obtain everything he wanted, since the lady was pregnant, he decided he had no other choice but to become her cofather; so having become friends with the lady's husband, in the most honorable way possible, he made his request to the husband, and it was accepted. Thus Rinaldo became her cofather, and now that he had a somewhat more plausible reason for speaking with her, he grew more confident, and with his words, he apprised her of his intentions, which she had long before guessed from the look in his eyes, but it did him little good. ${ }^{32}$

This passage and the previous one from Story VII, 10 point out that in theory even male and female baptismal kin could visit one another without arousing suspicion. In fact Rinaldo here was able "to visit his comother quite often." Most likely, the supposed innocent - or safe - character of these visits stemmed from the perceived strength of the sexual taboo arising from the cognatio spiritualis. This is also an aspect of baptismal kinship in Latin America today where compadres are among the small circle of males allowed to visit unchaperoned married women. ${ }^{33}$ Both Tingoccio and Rinaldo, however, use this privilege for illicit purposes. It is of interest that 
Rinaldo, the prospective cofather in this story, initiates the baptismal kinship relationship not the father of the child. Rinaldo offers to stand sponsor, not waiting to be asked. This is not all that out of character for Florentines. Giovanni Morelli, in recounting how his father curried favour with the rich and powerful, noted that to make friends and allies one should offer to stand godfather to their children; or as he puts it, "to baptize their children" (battezare loro figliuoli). ${ }^{34}$ Florentines recognized the utility - and strength - of the bonds of friendship emanating from the cognatio spiritualis. In Rinaldo's case, however, his interest is not friendship but something else.

Yet, in the course of the story, Rinaldo becomes a friar, a good holy one at first. "He had," Boccaccio notes, "from the time he became a friar put aside the love he bore his comother, as well as a couple of his other worldly vices." Boccaccio tells us flatly here that loving a comother was sinful. And Rinaldo recognized this sinfulness. Falling away from his saintly life, however, Rinaldo once again pursued his comother. At one point he told her: "I'm not saying it's [having sex with a coparent] not a sin, but God forgives even greater sins as long as you repent." 35

Despite Agnessa's resistance, Rinaldo persists. When he tells the woman he wishes to make love to her, she replies, "Oh dear, poor me, you are my cofather; how could you do such a thing? It would be terribly wicked, and I have heard many times that it is a serious sin; if it weren't for that I would be happy to do what you like." This response indicates that the Florentine perception of the sexual taboos formed in baptismal kinship operated on two levels. Agnessa says that having sex with a coparent would be wicked (troppo gran male); she perceives, therefore, that the act itself is inherently wrong. This is how modern Latin American popular culture perceives the violation of the baptismal kinship sexual taboos. ${ }^{36}$ Agnessa also says that she accepts the opinion of established authority that having sex with a coparent is sinful (troppo gran peccato). ${ }^{37}$ So for her having sex with a coparent is both morally repugnant and illegal - much as how consanguinal incest has been perceived through history. Agnessa also notes that she has frequently heard (io ho molte volte udito) about the sexual prohibitions. This reflects the presence of an oral tradition about baptismal kinship and spiritual incest (even Aquinas relied on a popular verse to explain the dimensions of spiritual incest), especially one nurtured by the Church whenever banns were announced and in confession.

Rinaldo is a persistent and ingenious fellow and decides to use logic on Agnessa:

"You are a foolish woman if you pass this up for that reason. I'm not saying it's not a sin, but God forgives even greater sins as long as you 
repent. But tell me something: who is a closer relative to your son, I who held him at his baptism, or your husband by whom he was begotten?"

The lady answered: "My husband is more closely related."

"That is correct," remarked the friar, "and doesn't your husband sleep with you?"

"Of course he does," the lady replied.

"Therefore," concluded the friar, "since I am less closely related to your son than your husband is. I should also be able to sleep with you the way your husband does." 38

Here Boccaccio parodies the Church's reasoning on why baptismal kin should not have sexual relations, why baptismal kinship erected an impediment to marriage. According to Aquinas, who was relying on Peter Lombard: "The holier the bond the more it is to be safeguarded. Now a spiritual bond is holier than a bodily tie; and since the tie of bodily kinship is an impediment to marriage, it follows that spiritual relations should also be an impediment." 39 The Council of Florence echoed these sentiments when it declared that spiritual ties were more significant than bodily ties because the spirit was more important than the body. ${ }^{40}$ Rinaldo reverses that reasoning. Boccaccio's wit here demonstrates, if nothing else, that he understood the taboos and the Church's reasons for them well enough to make light of them. In fact, at the end of Story VII, 10, when Meuccio discovers that having sex with one's comother does not count for much in Hell, Boccaccio concludes by noting: "If Brother Rinaldo had known these things, there would have been no need for him to go about dreaming up syllogisms when trying to convert his worthy comother to his pleasures." 41

And Boccaccio's passage here in Story VII, 3 implies his audience too understood the taboos. The story continues: "The lady, who was unskilled at logic and was in need of very little persuasion, either really believed or intended to believe that what the friar said was true, and she answered: 'who could ever refute such wise words?' " That she may have pretended to believe Rinaldo's syllogism sharpens the probability that Florentines had common knowledge of the Church's syllogism. Agnessa caves in to Rinaldo's insistence and logic: “And then in spite of their spiritual relationship (il comparatico), she proceeded to fulfill all his desires." 42

In fact, they sleep together many times aided by the supposedly safe nature of coparent visits: "concealed under the cover of this special relationship with her son, which gave him better opportunities with less suspicion, they met together more and more often." But nothing last forever. 
One day the husband comes home early. The wife, to explain away their cofather's presence in their bedroom as well as to give him time to dress, tells her husband that Rinaldo had come over to exorcise their son. The cuckold accepts the story (Boccaccio calls him a fool, il santuccio); and he is so happy to see his cofather, who he believes has just rendered him an inestimable service, that he lays out his best wine and food to honor him for his visit. ${ }^{43}$ The cuckold at least is upholding his responsibilities and duties as a coparent. Thus to an old motif, that of the duped husband, Boccaccio introduced Florentine baptismal kinship practices.

What do we make of all this? Working back and forth between text and context we note that the sexual taboos arising from medieval Florentine baptismal kinship did penetrate to the popular level. Boccaccio's stories here are inexplicable and even pointless without this conclusion. Also, working back and forth between text and context, we understand Boccaccio and his culture that much more. The joke we do not get as twentieth-century intruders into a past culture becomes clearer. ${ }^{44}$ Tingoccio does not just enjoy illicit sex; he enjoys illicit sex with his comother. Rinaldo does not just commit adultery with his neighbor's wife; he commits adultery with his comother. Rinaldo does not just cuckold a friend; he cuckolds his cofather. In the context of medieval Florentine culture, these violations of sexual mores are that much worse because they violated the rules of baptismal kinship. And Boccaccio added these tidbits about baptismal kinship practices not to express disbelief in the cognatio spiritualis and the sexual taboos arising out of it but to add wit, irony, and realism to his stories. Boccaccio's renditions of these stories, these old motifs, are that much more biting, that much more pungent because of these additions.

\section{University of Illinois Urbana-Champaign}

Note: I would like to thank Donald E. Queller, Mark Angelos, Joseph H. Lynch, James A. Brundage, William A. Stephany, and especially the late John F. McGovern for their help and encouragement in the writing of this article.

1 Julian Pitt-Rivers, "Pseudo-Kinship," International Encyclopedia of the Social Sciences, 8 (New York, 1968), pp.408-13.

2 S. Gudeman, "Spiritual Relations and Selecting a Godparent," Man, 10 (1975), 223. The anthropologist George Foster claims that rural Latin American society would collapse without the baptismal kinship network: George Foster, "Godparents and Social Networks in TzinTzunTzan," Southwestern Journal of Anthropology, 25 (1969), 262. The anthropological literature dealing with baptismal kinship is legion. For the most up-to-date accounting see the bibliographies and bibliographical essays in Hugo Nutini and Betty Bell, Ritual Kinship: The Structure and Historical Development of the Compadrazgo System in Rural Tlaxcala (Princeton, 1980), I, and Hugo Nutini, Ritual Kinship: Ideological and Structural Integration of the Compadrazgo System in Rural Tlaxcala (Princeton, 1984), II. 
3 Michael Bennet, "Spiritual Kinship and the Baptismal Name in Traditional Society," in Principalities, Power and Estates, ed. L. O. Frappel (Adelaide, 1979), pp.1-14; John Bossy, "Blood and Baptism: Kinship, Community and Christianity in Western Europe, 14th-17th Centuries," in Studies in Church History, ed. D. Baker (Oxford, 1973), X,13-35; "Padrini e madrini: un istituzione sociale del cristianesimo popolare in Occidente," Quademi storici, 14 (1979), 440-49; "Godparenthood: The Fortunes of a Social Institution in Early Modern Christianity," in Religion and Society in Early Modern Europe 1500-1800, ed. Kaspar von Greyerz (London, 1984), pp.194-201; Joseph H. Lynch, Baptismal Sponsorship and Monks and Nuns 500-1000," American Benedictine Review, 31 (1980), 108-29; "Hugh I of Cluny's Sponsorship of Henry IV: Its Context and Consequences," Speculum, 60 (1985), 800-26; Godparents and Kinship in Early Medieval Europe (Princeton, 1986); Philip Niles, "Baptism and the Naming of Children in Late Medieval England," Medieval Prosopography, 3 (1980-2), 95-107.

4 Code 5. 4. 26. 2, dated 530. James A. Brundage, Law, Sex, and Christian Society in Medieval Europe (Chicago, 1987), p.193.

5 Gudeman, pp.230-32. See also Joseph H. Lynch, "Spiritual Kinship and Sexual Prohibitions in Early Medieval Europe," in Proceedings of the Sixth International Congress of Medieval Canon Law (Berkeley, California, August 1980), Monumenta iuris canonici C/7 (Vatican City, 1985), pp.271-88. The Summa Theologica of St. Thomas Aquinas: Third Part (Supplement), trans. The Fathers of the English Dominican Province (London, 1922), p.242. According to Richard Trexler, "Godparents by their act of sponsorship set up another spiritual relationship whose carnal violation was incest," Synodal Law in Florence and Fiesole (Vatican City, 1971), pp.67-68.

6 Of the 557 papal dispensations to England listed in the Calendar of Entries in the Papal Registers: Papal Letters, II-VIII (London, 1895-1909) for the years $1305-1447$ for all manner of marital impediments - kindred, affinal, and spiritual - forty-six, or $8 \%$, concerned spiritual kinship. Some married couples, the petitions noted, had been living apart for years after discovering that they were baptismal kin. At least in England some people perceived and acted on the taboo. When the episcopal court at Constance debated marital impediments in the fifteenth and sixteenth centuries, that of spiritual kinship was the most frequently discussed. Thomas Max Safley, Let No Man Put Asunder: The Control of Marriage in the German Southwest: A Comparative Study, 1550-1600 (Kirksville, 1984), p.22.

7 According to Lynch, "Literary texts have the potential to complement the normative texts, especially by indicating the ways in which the Christian populace shaped, adapted, elaborated, and extended the consequences of a liturgical ritual.

Almost always, spiritual kinship in a literary text is a secondary matter, a detail woven into the work, or a part of its sociocultural background." Lynch, Godparents and Spiritual Kinship, pp.44-45.

8 These stories are I, 2; IV, 2; VI, 10; VII, 3 and 10; IX, 10; and X, 4. Lee notes that none of Boccaccio's stories detailing baptismal kinship have any antecedent dealing with baptismal kinship. A. C. Lee, The Decameron Its Sources and Analogues (London, 1909), pp.2-6, 123-35, 189-91, 245, 291-3. That Boccaccio depicted the world of the Florentine merchant elite is almost too well-known of a truism to mention. See Thomas G. Bergin, Boccaccio (New York, 1981), especially Chapter 19. De Sanctis comments that fourteenthcentury Tuscan "society was taken bodily just as it was, warm, palpitating, vividly alive, and was put into the Decameron. The book is an immense picture of life in all its variety of the characters and the events most calculated to make people marvel." Francesco De Sanctis, "Boccaccio's Human Comedy," in Critical Perspectives on the Decameron, ed. Robert S. Dombroski (London, 1976), p.35. 
9 For a preliminary look at some aspects of Florentine baptismal kinship, see Christiane Klapisch-Zuber, Women, Family, and Ritual in Renaissance Italy (Chicago, 1985), pp.68-93, 237-8, 241, 283-310.

10 Jacques LeGoff comments that the eighth through the twelfth centuries "saw the emergence of a new story type, a genre that helped popularize Purgatory in the thirteenth century. In these tales the souls of the dead undergoing punishment in Purgatory appear to the living and asked for suffrages or warned them to mend their ways before it was too late." Godparents figured prominently in these stories as the individual returning from Purgatory. Jacques LeGoff, The Birth of Purgatory (Chicago, 1984), pp.177-79.

11 Giovanni Boccaccio, The Decameron, trans. Mark Musa and Peter Bondanella (New York, 1982), pp.468-70. This is perhaps the best English translation of The Decameron, and it certainly retains the earthy and robust nature of the original. However, Musa and Bondanella consistently fail to identify the significance of the baptismal kinship relationship. They abandon the Italian comare and compare for clumsy phrases like "my godchild's mother." I have rendered these terms as "comother" and "cofather," which retain the exact sense of the baptismal kinship relationship. For comparison with the Italian I have used Giovanni Boccaccio, Decameron, ed. Vittore Branca (Florence, 1976), pp.496-99.

12 The Decameron, p.469.

13 Ibid.

14 Ibid.

15 Ibid., p.470.

16 Robert Darnton, The Great Cat Massacre and Other Episodes in French Cultural History (New York, 1984), pp.4-5, 262-63.

17 See on this not only Trexler but Robert Brentano, Two Churches England and Italy in the Thirteenth Century (Princeton, 1968).

18 Trexler, pp.62-63, 68-69, 102, 126.

19 Giovanni Domenico Mansi, ed. Sacrorum Conciliorum Nova et Amplissima Collectio 35, 1414-1724 (Paris, 1902), pp.250-51.

20 Ibid.

21 Trexler, p.68.

22 Ibid.

23 Florentines sometimes recorded in their ricordanze (diary-like account books) the names of their coparents, who were also the godparents of their children. For instance, on 4 August 1411 Gregorio Dati had his colleagues from the Standard-bearers of the Militia Companies become godfathers to his son Niccol.For the baptism of his son Girolamo Domenico on 1 October 1412, the "sponsors [cofathers] were Master Bartolomeo del Carmine, Cristofano di Francesco di Ser Giovanni, and Lappuccio di Villa, and his son Bettino. 'The Diary of Gregorio Dati," Two Memoirs of Renaissance Florence, trans. Julia Martines, ed. G. Brucker (New York, 1967), p.128.

24 Trexler, pp.62-63, 68-69, 106.

25 On late medieval confessor's manuals and their effect on the European populace, see Thomas Tentler, Sin and Confession on the Eve of the Reformation (Princeton, 1977). Tentler presents adequate evidence showing how well - perhaps too well - these manuals and the confessors communicated the nature and consequences of late medieval sin to their parishioners. 
26 These questions are contained under the rubric Della Luxuria in a section describing the different types of incest the confessor and penitent should be wary of. For men the confessor was to ask: "Se stato con comare o sua figluola [meaning his goddaughter] $o$ chon altra che vista suto pecchato spirituale." For women: "Se stato con tuo compare o suo attenente." Libro della confessione (Biblioteca Nazionale Centrale, Florence, Landau Finlay, 288 , fols. 20v, 25v). "[A]udivit in confessio et dicit incestus vel sacrilegiu." St. Antoninus, Confessionale (Venice, 1474), fol. 34v.

27 San Bernardino, Le Prediche Volgari, ed. C. Cannarozzi, I (Pistoia, 1934), p.200.

28 David Herlihy and Christiane Klapisch-Zuber, Tuscans and Their Families: A Study of the Florentine Catasto of 1427 (New Haven, 1985), p.210.

29 Florentines knew well that without baptism salvation was impossible; they knew where Dante had placed unbaptized children - between Purgatory and Hell. And when it came to baptism, Florentines acted quickly: a close reading of the manuscript and published ricordi and ricordanze shows that virtually all Florentine children were baptized within three days of birth, some within hours of birth. According to Giovanni Morelli, "Sabato a di dieci di marzo, tra le diciotto e le diciennove ore, anno Domini 1396, nacque Alberto mio figliuolo e della Caterina mia donna; e nacque in casa Aliso. Battezzossi a di tredici del detto mese in San Giovanni di Firenze." Giovanni Pagolo Morelli, Ricordi, ed. Vittore Branca (Florence, 1969), p.358.

30 Trexler, pp.201, 235, 267.

31 Summa Theologica, 241-43. On impedient versus diriment impediments to marriage, see Brundage, pp.193-95, 289, 305.

32 The Decameron, p.426; Decameron, pp.425-29.

33 Charles J. Erasmus, "Current Theories of Incest Prohibition in the Light of Ceremonial Kinship," Kroeber Anthropological Papers, 2 (1950), 45.

34 Morelli, p.237.

35 The Decameron, p.427.

36 In Latin America sexual relations between coparents or between godparents and godchildren are especially reprehensible. According to Yucatan belief, coparent incest is worse than mother-son incest. In Tenia, Mexico, coparents who have sexual relations with one another are said to become water snakes when they die (Erasmus, 44-45). A medieval story told about Robert the Pious demonstrates as well "the tetralogical consequences of intermarriage" between baptismal kin. He married his comother and their first child had a "neck and a head like a goose." Georges Duby, The Knight, The Lady and The Priest The Making of Modern Marriage in Medieval France (New York, 1983), pp.84-85.

37 Tingoccio also saw the act as wicked and sinful.

38 The Decameron, pp.427-28.

39 Summa Theologica, p.235. Peter Lombard, Sententiarum Liber Quattuor (Paris, 1892), p.711.

40 Mansi, pp.250-51.

41 The Decameron, p.470.

42 The Decameron, p.428.

43 Ibid., pp.426-30. For another perspective on this story, which also touches on the spiritual kinship element, see Steven M. Grossnogel, "Frate Rinaldo's Paternoster to Saint Ambrose (Decameron VII 3)," Studi sul Boccaccio, 13 (1981-82), 161-67. 
44 Musa and Bondanella, however, never did get the joke. When they have to use the terms "comare" and "compare" because the characters in VII, 3 use them as terms of address, they leave them untranslated, despite having mistranslated "comare" as "neighbor" in IV, 2. In VII, 3, Musa and Bondanella explain: "In this context, comare and compare are friendly terms of address still in use in the south of Italy, and they have no real equivalent in English. Literally, the words mean 'godmother' and 'godfather.' In this instance it just happens that the compare and family friend, Brother Rinaldo, really is the godfather of the child in question" (The Decameron, p.429). "Comare" and "compare" mean much more than just "friendly terms of address," and they do not literally mean "godmother" and "godfather" only. It is no mere coincidence that Rinaldo is both cofather and family friend, all of which we have seen above. Translators and editors dealing with stories I, 2; IV, 2; VI, 10; VII, 3 and 10; IX, 10; and X, 4 will have to pay closer attention to the social context of these texts in the future. 